\title{
Adherence to Prescribed Oral Medication in Adult Patients Undergoing Chronic Hemodialysis: A Critical Review of the Literature
}

\author{
H. Schmid ${ }^{1}$, B. Hartmann ${ }^{2}$, H. Schiffl ${ }^{1}$ \\ ${ }^{1}$ KFH Nierenzentrum Muenchen Laim, Munich, Germany, \\ ${ }^{2}$ Department of Nephrology, Medical Clinic I, University Hospital Munich-Grosshadern, Munich, Germany
}

\begin{abstract}
Objective: Poor adherence to complex multimodal therapies is a widely recognized problem in the daily care of dialysis patients, contributing to excess morbidity and mortality of this population. While a few studies have been devoted to understanding patient nonadherence, their results were somewhat controversial. The goals of this review are to quantify nonadherence to certain oral medications, to raise awareness of factors that may cause problems in a patient's adherence to this treatment, and to describe strategies that may be used to improve adherence to prescribed pharmacotherapy.

Methods: A systematic literature review in the MEDLINE and PubMed database (1971-2008) was performed. Quantitative studies, which accurately indicated the total percentages of nonadherence to oral medication in adult patients receiving chronic hemodialysis, were identified.

Results: A total of 19 studies fulfilled the search criteria. Rates of nonadherence to the oral medication ranged from $3-80 \%$. More than half of the included studies reported nonadherence rates of $\geq 50 \%$ (mean $67 \%$ ). The use of phosphate binding therapy was the prevalent surveyed oral medication. Self reports, structured interviews, and predialysis serum phosphate levels were the most frequent assessment tools used to record adherence rates. Limitations of the reviewed studies included small patient cohorts, inconsistent definitions of adherence, and a lack of standardized methods for measuring nonadherence.

Conclusions: Nonadherence to oral medication in hemodialysis patients is still an underestimated, but lifethreatening behaviour.
\end{abstract}

Key words: Adherence, compliance, hemodialysis, medication, prescription

\section{INTRODUCTION}

The prevalence and incidence of chronic kidney disease stage $\mathrm{V}$ (end-stage renal disease) are continuously increasing, particularly in elderly patients [1]. Endstage renal disease (ESRD) is not simply a mono-organ failure, but rather a systemic disorder affecting a number of other organ systems. Despite significant advances in the technology of renal replacement therapy (RRT), no current modality of blood purification serves as a substitute for all renal functions. RRT undoubtedly contributes to long-term survival. However, morbidity and mortality of maintenance dialysis patients remain high: only about one third of the US hemodialysis (HD) patients are alive after 5 years [2]. Cardiovascular diseases are the leading cause of death in ESRD patients [3]. Notably, patients with ESRD have a very high prevalence of cardiovascular disease risk factors such as diabetes and hypertension, but they are also exposed to other non-traditional, uremiarelated cardiovascular disease risk factors, particularly derangements in calcium and phosphate metabolism [4]. Given the complexity of these cardiovascular risk factors in ESRD patients, it presents a challenging target for therapy. To modify these risk factors such as hypertension or secondary hyperparathyroidism, the HD patient has to take an average of 6-12 tablets per day $[5,6,7]$.

Successful RRT of ESRD patients relies on patient adherence to various aspects of the therapy, such as attendance to the number of sessions prescribed to achieve the optimal dose of RRT, restriction of fluid intake, following dietary guidelines, and adherence to complex medical regimens $[8,9,10,11]$. There is solid evidence that adherence of ESRD patients correlates with morbidity and mortality [12]. Specifically, skipping treatment and poor dietary adherence are strongly associated with greater risk for death [13]. Unfortunately, poor adherence (compliance) with prescribed medication is a widely recognized problem in daily practice, but few studies have been devoted to understanding patient nonadherence to medication [14]. Furthermore, criteria to assess nonadherence to prescribed oral medications are often arbitrary and are not linked to defined clinical outcomes.

The goals of this literature review are: i) to quantify nonadherence to drugs preventing or treating secondary hyperparathyroidism, or to antihypertensive drugs, ii) to raise awareness of factors that may cause problems in patient adherence to these treatment programs, and iii) to describe strategies that may be used to improve adherence to prescribed medication.

\section{Materials AND Methods}

We conducted a systematic literature review in the online databases MEDLINE and PubMed (1971-2008) using a comprehensive list of relevant search terms 
(adherence/nonadherence, compliance/noncompliance, medication/drug, dialysis/hemodialysis, renal replacement therapy, end-stage renal disease/chronic renal failure) to identify studies on oral medication adherence among adult HD patients. We limited our review to those articles that accurately indicated total percentages or rates of nonadherence to oral medication in the HD population. The systematic literature research identified a total of 387 published articles that contained a combination of the search terms in the abstract. The vast majority (368) of these articles were qualitative studies, review articles, or case reports. Articles focusing on pediatric adherence (patients under 18 years of age) were excluded.

\section{RESULTS}

Only 19 studies reported total rates of nonadherence to oral medication among adult HD patients. Key information is summarized in Table 1.

The selected articles showed a wide variation with regard to the sample size, varying from a minimum of 19 patients [15] to a maximum of 6251 patients [16]. Seven out of 19 studies (37\%) included a total number of less than 50 patients.

Phosphate binders (PB, 18/19 studies), antihypertensive drugs (AHT, 11/19 studies), or oral calcium supplementation including the vitamin D analog calcitriol (CAS, 8/19 studies) were the prevalent surveyed oral medications.

Self reports or structured interviews (patient self reports, PSR, 16/19 studies, 84\%) were the most frequently used tools to assess adherence rates. Predialysis serum phosphate (9/19 studies, 47\%) was commonly used as an adherence indicator for patients taking the oral prescribed phosphate binding medication. Limit values for predialytic phosphate levels showed a broad amplitude from $>4.5 \mathrm{mg} / \mathrm{dl}$ [15] to $>7.5 \mathrm{mg} / \mathrm{dl}$ [16]. Only two studies by Curtin and coworkers [17, 6] used medication event monitoring devices (MEMS) to monitor patient's adherence.

Quantitative rates of nonadherence to oral medication substantially varied in the reviewed studies, and estimates of the percentage of nonadherent participants ranged from $3-80 \%$. More than half of the included studies $(11 / 19,58 \%)$ reported nonadherence rates of $\geq 50 \%$ (mean $67 \%$ ).

A history of long-term HD [18], older age (>65 years) [17], higher educational level [19], lower medication costs $[20,21]$, as well as little concerns about potential adverse effects were identified as markers for adherence. Among psychosocial variables an internal locus of control orientation (defined as a high expectation that one's actions have a causal relationship with the produced consequences) [15] and perceived barriers were most significantly associated with good adherence [22].

\section{Discussion}

To determine the frequency and prevalence of nonadherence in patients with ESRD undergoing HD, a clear-cut and consistent definition of these terms is essentially needed.
Owing to the inconsistencies in uniform definitions, widely divergent results have been obtained in different studies, so that as many as $80 \%$ of $\mathrm{HD}$ patients may be considered noncompliant with oral medication [23, 24, 8, 18]. The data of the selected 19 studies revealed that the calculated median is closer to $50 \%$ [25].

Standardized adherence parameters that can be easily measured and verified would be desirable to achieve reproducible and accurate rates of nonadherence. Nonadherence rates to oral medication are most frequently assessed by predialytic serum phosphate levels. However, serum phosphate level is not only influenced by the phosphate binder therapy itself, but also by diet restrictions, dialysis attendance and residual renal function, revealing the lack of specificity particularly in regard to comorbid illness and the patient's nutritional status. This could be a possible explanation for the weak correlations between adherence rates estimated by self reports and phosphate measurements.

To date, there is little consensus among researchers about standardized methods for measuring nonadherence. Assessment tools for evaluation of adherence in the HD population include direct and indirect monitoring methods (summarized in Table 2).

Microelectronic monitoring devices (MEMS) [26] are recently introduced microchips incorporated into drug container caps and offer a reliable and objective source of adherence data $[27,28]$. MEMS are expensive, but monitoring 1 or 2 medications, chosen as "sentinel" drugs, is usually sufficient to determine adherence $[26,29]$. Marked differences in rates of nonadherence as measured by the MEMS versus self reports were observed: MEMS recorded $52 \%$ of the HD patients as repeatedly nonadherent for antihypertensive medication and $70 \%$ as repeatedly noncompliant for phosphate binder medication, whereas evaluation of self reports only identified $12 \%$ and $8 \%$, respectively $[17,6]$.

Factors associated with nonadherence in HD patients, mainly based on expert opinion, are similar to those for other chronic conditions and can be subdivided into demographic, clinical and psychosocial predictors (summarized in Table 3) [30].

Among the most frequently assessed demographic predictors of oral medication adherence, age seems to be a strong predictor of nonadherence in patients with ESRD undergoing HD in most, albeit not all studies. Some articles reported that older age, particularly $>65$ years, was associated with higher levels of adherence $[31,32,24,33,23,34]$. This is in contrast to recent observations, reporting an emerging cognitive impairment and dementia in the aging dialysis population $[35,36]$.

The complexity of the prescribed medication regimen is another crucial predictor of nonadherence, as prescribed number of doses seems to be inversely related to adherence [26]. Unfortunately, once-daily dosing as latterly introduced in the therapy for HIV-infected patients as well as for transplant recipients is unrealistic for the multimorbid adult HD patient [37, 38].

In addition to treatment complexity and high pill burden, also the size and taste of phosphate binding tablets may impact adherence to prescribed oral med- 
Table 1. Studies in a chronological order focusing on adherence to prescribed oral medication in adult HD patients.

\begin{tabular}{|c|c|c|c|c|c|}
\hline Study, year & $\begin{array}{l}\text { Included } \\
\text { patients }\end{array}$ & $\begin{array}{l}\text { Medication } \\
\text { type }\end{array}$ & $\begin{array}{l}\% \text { Non- } \\
\text { adherent }\end{array}$ & $\begin{array}{l}\text { Nonadherence } \\
\text { definition } \\
\text { /assessment }\end{array}$ & Results \\
\hline $\begin{array}{l}\text { Wenerowicz, } \\
1978[15]\end{array}$ & 19 & PB & 60 & $\begin{array}{l}\mathrm{P}>4.5 \mathrm{mg} / \mathrm{dl} \\
\text { PSR (questionnaire) }\end{array}$ & $\begin{array}{l}\text { Patients with internal locus of control }{ }^{1} \\
\text { orientation showed higher compliance } \\
\text { than with external locus }\end{array}$ \\
\hline $\begin{array}{l}\text { Cummings, } \\
1982[51]\end{array}$ & 116 & PB & 70 & $\begin{array}{l}\mathrm{P}>5.5 \mathrm{mg} / \mathrm{dl} \\
\text { PSR (interview) }\end{array}$ & $\begin{array}{l}\text { Situational factors and psychosocial } \\
\text { variables major contributors to adherence }\end{array}$ \\
\hline $\begin{array}{l}\text { Betts, } 1988 \\
{[52]}\end{array}$ & 46 & PB & 74 & $\begin{array}{l}\mathrm{P}>5 \mathrm{mg} / \mathrm{dl} \\
\text { PSR (questionnaire) }\end{array}$ & $\begin{array}{l}\text { Length of time on } \mathrm{HD} \text {, age, educational } \\
\text { level and response to illness not signifi- } \\
\text { cantly related to adherence }\end{array}$ \\
\hline $\begin{array}{l}\text { Weed-Collins, } \\
1989 \text { [22] }\end{array}$ & 30 & PB & 64 & $\begin{array}{l}\mathrm{P}>5.5 \mathrm{mg} / \mathrm{dl} \\
\text { PSR (questionnaire) }\end{array}$ & $\begin{array}{l}\text { Perceived barriers ("forgetting" and "be- } \\
\text { ing away from home") most significant } \\
\text { predictors of compliance, women signifi- } \\
\text { cantly more compliant }\end{array}$ \\
\hline $\begin{array}{l}\text { Blanchard, } \\
1990 \text { (53) }\end{array}$ & 40 & PB, CAS, Vits & 28 & $\begin{array}{l}\text { PSR } \\
\text { (questionnaire) }\end{array}$ & $\begin{array}{l}\text { Majority of HD patients knew dosing } \\
\text { schedules but knowledge about drug } \\
\text { treatment was grossly deficient }\end{array}$ \\
\hline $\begin{array}{l}\text { Bame, } 1993 \\
{[23]}\end{array}$ & 1230 & $\begin{array}{l}\text { PB, AHT, } \\
\text { CAS }\end{array}$ & 50 & $\mathrm{P}>6.0 \mathrm{mg} / \mathrm{dl}$ & $\begin{array}{l}\text { Prevalence of noncompliance consistent } \\
\text { with previous studies; older age and high- } \\
\text { er income associated with compliance }\end{array}$ \\
\hline $\begin{array}{l}\text { Kaplan, } 1994 \\
\text { [7] }\end{array}$ & 30 & PB, AHT & 67 & $\begin{array}{l}\text { PSR (questionnaire) } \\
\text { Reporting missing a } \\
\text { dose }\end{array}$ & $\begin{array}{l}\text { Drug selection and medication compli- } \\
\text { ance contained greatest number of poten- } \\
\text { tial problems }\end{array}$ \\
\hline $\begin{array}{l}\text { Cleary, } 1995 \\
{[18]}\end{array}$ & 51 & $\begin{array}{l}\text { AHT, PB, } \\
\text { CAS, Vits }\end{array}$ & 61 & $\begin{array}{l}\mathrm{P}>4.5 \mathrm{mg} / \mathrm{dl} \\
\text { (interview) }\end{array}$ & $\begin{array}{l}\text { Patients with long-term HD more com- } \\
\text { pliant with AHT and CAS than with PB }\end{array}$ \\
\hline Lin, 1997 [54] & 86 & $\mathrm{~PB}, \mathrm{CAS}$ & $24-61$ & $\begin{array}{l}\mathrm{P}>4.59 \mathrm{mg} / \mathrm{dl} \\
\text { PSR, nurses } \\
\text { assessment }\end{array}$ & $\begin{array}{l}\text { Multidimensional Health Locus of Con- } \\
\text { trol (MHLC) scale had only slight influ- } \\
\text { ence on measures of compliance }\end{array}$ \\
\hline $\begin{array}{l}\text { Curtin, } 1997 \\
{[17]}\end{array}$ & 135 & AHT, PB & $42-80$ & MEMS & $\begin{array}{l}\text { Patients } \leq 65 \mathrm{yrs} \text { made more dosing } \\
\text { errors with AHT and missed taking PB } \\
\text { on more days than patients }>65 \mathrm{yrs}\end{array}$ \\
\hline $\begin{array}{l}\text { Leggat, } 1998 \\
\text { [16] }\end{array}$ & 6251 & PB & 22 & $\mathrm{P}>7.5 \mathrm{mg} / \mathrm{dl}$ & $\begin{array}{l}\text { Younger patients and smokers with high- } \\
\text { er rates of noncompliance; blacks signifi- } \\
\text { cantly less noncompliant than whites }\end{array}$ \\
\hline $\begin{array}{l}\text { Curtin, } 1999 \\
{[6]}\end{array}$ & 135 & AHT, PB & 73 & $\begin{array}{l}\text { PSR, pill count, } \\
\text { MEMS }\end{array}$ & $\begin{array}{l}\text { African-Americans with higher rates of } \\
\text { noncompliance }\end{array}$ \\
\hline $\begin{array}{l}\text { Caraballo } \\
\text { Nazario, } 2001 \\
(19)\end{array}$ & 53 & \multicolumn{2}{|c|}{ AHT, PB, CAS 75} & $\begin{array}{l}\text { PSR, Reporting } \\
\text { missing a dose } \\
\text { (structured interview) }\end{array}$ & $\begin{array}{l}\text { Significant association between compli- } \\
\text { ance and educational level }\end{array}$ \\
\hline $\begin{array}{l}\text { Horne, } 2001 \\
{[55]}\end{array}$ & 47 & \multicolumn{2}{|c|}{ AHT, PB, CAS 57} & $\begin{array}{l}\text { PSR, } \\
\text { Reporting missing a } \\
\text { dose (self report) }\end{array}$ & $\begin{array}{l}\text { Nonadherence correlated with concerns } \\
\text { about potential adverse effects of medica- } \\
\text { tion }\end{array}$ \\
\hline $\begin{array}{l}\text { Tomasello, } \\
2004[56]\end{array}$ & 129 & PB & $38-51$ & $\begin{array}{l}\text { PSR (taking }<80 \% \\
\text { of medication), } \mathrm{P} \\
>5.5 \mathrm{mg} / \mathrm{dl}\end{array}$ & $\begin{array}{l}\text { Compliance did not account for the large } \\
\text { difference in prescribed pill burden }\end{array}$ \\
\hline $\begin{array}{l}\text { Rahman, } \\
2004 \text { [57] }\end{array}$ & 205 & AHT & 23 & $\begin{array}{l}\text { PSR, Reporting } \\
\text { missing a dose }\end{array}$ & Good adherence to AHT therapy \\
\hline $\begin{array}{l}\text { Holley, } 2006 \\
{[20]}\end{array}$ & 39 & AHT, PB & 21 & $\begin{array}{l}\text { PSR, } \\
\text { Reporting missing a } \\
\text { dose (structured } \\
\text { interview) }\end{array}$ & $\begin{array}{l}\text { Inadequate prescription coverage, lack of } \\
\text { transportation, and medication cost con- } \\
\text { tribute to noncompliance }\end{array}$ \\
\hline $\begin{array}{l}\text { Lindberg, } \\
2007[58]\end{array}$ & 144 & $\begin{array}{l}\text { AHT, PB, } \\
\text { CAS, Vits }\end{array}$ & 80 & $\begin{array}{l}\text { Discrepancy } \\
\text { between self-report } \\
\text { and medication list }\end{array}$ & $\begin{array}{l}\text { Deviation between consumption and pre- } \\
\text { scription in chronic HD patients }\end{array}$ \\
\hline $\begin{array}{l}\text { Hirth, } 2008 \\
\text { [21] }\end{array}$ & 5478 & $\begin{array}{l}\text { AHT, PB, } \\
\text { CAS }\end{array}$ & $3 *-29 * *$ & $\begin{array}{l}\text { Reporting costre- } \\
\text { lated nonadherence } \\
\text { (questionnaire) }\end{array}$ & $\begin{array}{l}\text { Cost-related nonadherence varies across } \\
\text { countries, substantial international varia- } \\
\text { tion }\end{array}$ \\
\hline
\end{tabular}

Abbreviations: PB Phosphate binder, AHT Antihypertensives, CAS Ca supplements including calcitriol, Vits Vitamins, MEMS medication event monitoring system, * Japan, ** USA; ${ }^{1}$ defined as a high expectation that one`s actions have a causal relationship with the produced consequences 
Table 2. Standard assessment tools for evaluation of adherence in the HD population.

\begin{tabular}{ll}
\hline Direct monitoring methods & Indirect monitoring methods \\
\hline assays of drug concentrations in biological fluids & patient self-reports (structured interviews, questionnaire) \\
use of markers incorporated into pills & compliance ratings by nurses \\
direct observation of pill taking & prescription refills \\
& pill counts \\
& microelectronic monitoring devices (MEMS) \\
\hline
\end{tabular}

Table 3. Factors associated with nonadherence in HD patients.

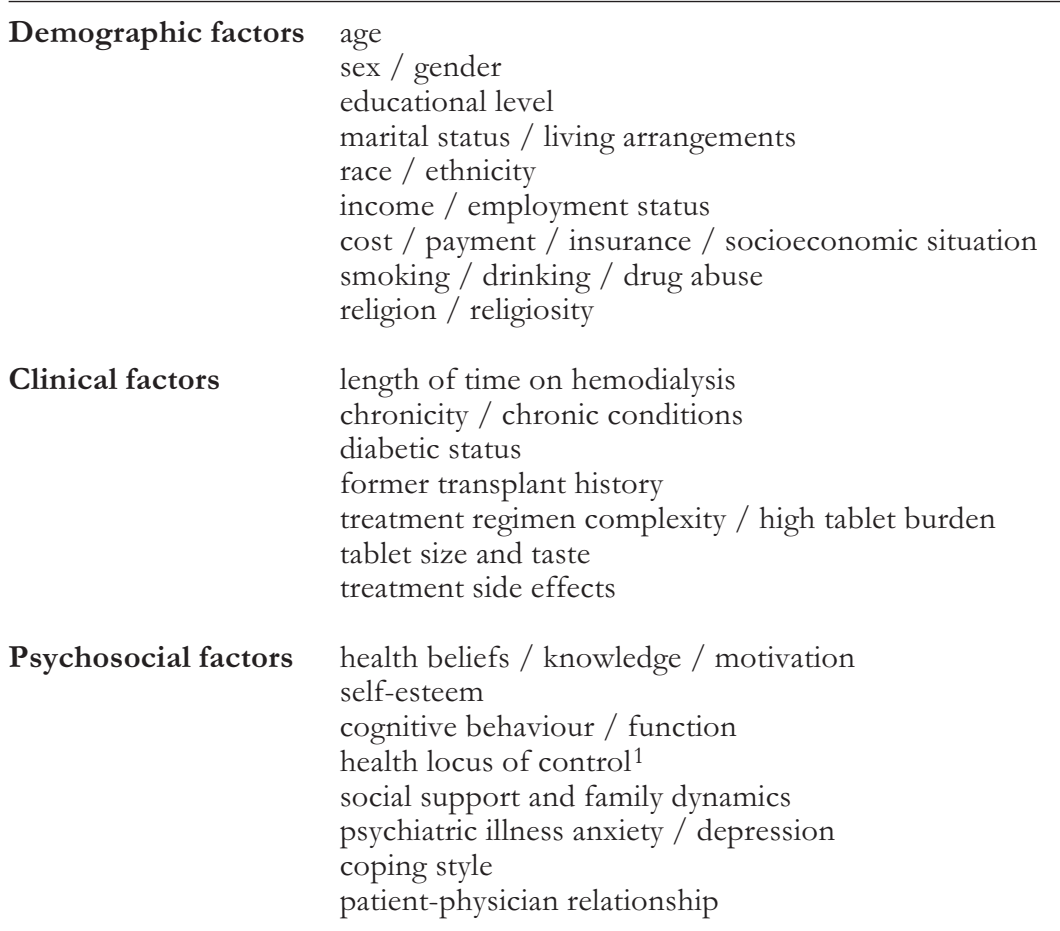

${ }^{1}$ defined as a high expectation that one `s actions have a causal relationship with the produced consequences.

Note: These factors are mainly based on expert opinion.

Table 4. Strategies to improve HD patient`s adherence to oral medication.

Improvement of interaction with the attending physicians and the nursing staff

Maintenance of contact with the patient and the patient`s family (empathy on adherence, trust)

Continuous education of the patient about the disease and its treatment

Establishment of the goals of therapy

Improvement of patient motivation

Awareness of medication-taking behaviour

Reduced complexity of treatment regimens (once-a-day formulations)

Early diagnosis of cognitive impairment

Note: While interventional studies are lacking in the HD population, the proposed strategies are predominantly based on expert opinion.

ication [39]. Novel compounds prescribed for phosphate binding in ESRD patients could circumvent high pill burden in the future. If the calcium- and aluminium-free lanthanum carbonate could provide ef- fective phosphate control with a lower tablet burden has to be elucidated [40].

HD patients are commonly affected by secondary hyperparathyroidism (SHPT), in which 3 well-known 
factors are usually involved: hypocalcemia, hyperphosphatemia, and calcitriol deficiency. Anecdotal reports showed that HD patients who receive any injectable vitamin $\mathrm{D}$ formulation have a survival advantage over comparable patients who receive no injectable vitamin $\mathrm{D}$ [41]. The intravenous administration of vitamin D or vitamin $\mathrm{D}$ analogs should further improve adherence in therapy for SHPT in HD patients. Several new vitamin $\mathrm{D}$ analogs, e.g. paricalcitol (19-nor-1,25(OH) 2D2), have been developed and investigated with the rationale to treat SHPT with a reduced risk of hypercalcemia and hyperphosphatemia [42].

Psychosocial variables, such as the extent of depression [43] and social support or family dynamics [44], are frequently related to outcome in ESRD patients treated with HD [45]. Particularly in regard to prescribed oral medication, an internal locus of control orientation [15] and perceived barriers (especially forgetting and being away from home) were significant predictors of compliance [22].

Patient motivation, empathy and trust are essential key factors to optimize patient adherence. As stated in "The Seventh Report of the Joint National Committee on Prevention, Detection, Evaluation, and Treatment of High Blood Pressure" [46], the "most effective therapy prescribed by the most careful clinician will control the disease only if the patients are motivated". In the development of empathy, attending physicians and the nephrology nursing staff play a pivotal role. Particularly, nephrology nurses are ideally placed to establish a partnership with the chronic HD patient [11]. The HD patient requires consistent and repeated education about their disease, treatment, and risks and benefits of adherence [47]. Interventional studies evaluating possible strategies to improve prescribed oral medication adherence are so far lacking in the dialysis population [48]. However, a single structured drug education program for HD patients yielded significant increases in medication knowledge and adherence within a control group [49]. To minimize nonadherence, interventions need to focus on both patient factors and the extent to which relationships and system problems compromise the patient's ability to adhere to medication treatment [50].

Taken together, a wide spectrum of useful strategies to improve medication adherence have been proposed, but most of them were not proved by interventional studies (summarized in Table 4). A patient-centered approach, including the removal of barriers to adherence, with improved communication, simplification of medication regimen, ongoing education, and the use of MEMS have been recommended as strategies to improve medication adherence. However, up to now, no single strategy has been definitely proven to yield universal and/or long lasting improvements in adherence.

\section{REFERENCES}

1. Hallan SI, Vikse BE. Relationship between chronic kidney disease prevalence and end-stage renal disease risk. Curr Opin Nephrol Hypertens. 2008;17(3):286-291.

2. United States Renal Data System. Excerpts from USRDS 2007 Annual Data Report. U.S. Department of Health and Human Services. The National Institutes of Health, National Institute of Diabetes and Digestive and Kidney Diseases. Am J Kidney Dis 2008; 1(Suppl 1):S1.
3. Cheung AK, Sarnak MJ, Yan G, Berkoben M, Heyka R, Kaufman A, Lewis J, Rocco M, Toto R, Windus D, Ornt D, Levey AS. Cardiac diseases in maintenance hemodialysis patients: results of the HEMO Study. Kidney Int 2004;65(6):2380-9.

4. Parfrey PS, Foley RN. The clinical epidemiology of cardiac disease in chronic renal failure. J Am Soc Nephrol 1999;10(7):1606-15

5. Manley HJ, Garvin CG, Drayer DK, Reid GM, Bender WL, Neufeld TK, Hebbar S, Muther RS. Medication prescribing patterns in ambulatory haemodialysis patients: comparisons of USRDS to a large not-for-profit dialysis provider. Nephrol Dial Transplant. 2004;19(7):18428 .

6. Curtin RB, Svarstad BL, Keller TH. Hemodialysis patients' noncompliance with oral medications. ANNA J. 1999;26(3):307-16.

7. Kaplan B, Mason NA, Shimp LA, Ascione FJ. Chronic hemodialysis patients. Part I: Characterization and drugrelated problems. Ann Pharmacother. 1994;28(3):316-9.

8. Safdar N, Baakza H, Kumar H, Naqvi SA. Non-compliance to diet and fluid restrictions in haemodialysis patients. J Pak Med Assoc. 1995;45(11):293-5.

9. Christensen AJ, Moran PJ, Wiebe JS, Ehlers SL, Lawton WJ. Effect of a behavioral self-regulation intervention on patient adherence in hemodialysis. Health Psychol. 2002;21(4):393-7.

10. Morales López C, Burrowes JD, Gizis F, Brommage D. Dietary adherence in Hispanic patients receiving hemodialysis. J Ren Nutr. 2007;17(2):138-47.

11. Barnett T, Li Yoong T, Pinikahana J, Si-Yen T. Fluid compliance among patients having haemodialysis: can an educational programme make a difference? J Adv Nurs. 2008;61(3):300-6.

12. ME O`Brien. Compliance behavior and long-term maintenance dialysis. Am J Kid Dis 1990, 15(3): 209-14.

13. Unruh ML, Evans IV, Fink NE, Powe NR, Meyer KB; Choices for Healthy Outcomes in Caring for End-Stage Renal Disease (CHOICE) Study. Skipped treatments, markers of nutritional nonadherence, and survival among incident hemodialysis patients. Am J Kidney Dis. 2005; 46(6):1107-16.

14. Constantini L. Compliance, adherence, and self-management: Is a paradigm shift possible for chronic kidney disease clients? CANNT J 2006, 16:4, $22-26$.

15. Wenerowicz WJ, Riskind JH, Jenkins PG. Locus of control and degree of compliance in hemodialysis patients. J Dial. 1978;2(5-6):495-505.

16. Leggat JE Jr, Orzol SM, Hulbert-Shearon TE, Golper TA, Jones CA, Held PJ, Port FK. Noncompliance in hemodialysis: predictors and survival analysis. Am J Kidney Dis. 1998;32(1):139-45.

17. Curtin RB, Svarstad BL, Andress D, Keller T, Sacksteder P. Differences in older versus younger hemodialysis patients' noncompliance with oral medications. Geriatr Nephrol Urol. 1997;7(1):35-44.

18. Cleary DJ, Matzke GR, Alexander AC, Joy MS. Medication knowledge and compliance among patients receiving long-term dialysis. Am J Health Syst Pharm. 1995;52(17): 1895-900.

19. Caraballo Nazario GL, Lebrón de avilés C, Dávila Torres RR, Burgos Calderón R. Kidney patients: aspects related to compliance with renal treatment. P R Health Sci J. 2001;20(4):383-93.

20. Holley JL, DeVore CC. Why all prescribed medications are not taken: results from a survey of chronic dialysis patients. Adv Perit Dial. 2006;22:162-6.

21. Hirth RA, Greer SL, Albert JM, Young EW, Piette JD. Out-of-pocket spending and medication adherence among dialysis patients in twelve countries. Health Aff (Millwood). 2008;27(1):89-102. 
22. Weed-Collins M, Hogan R. Knowledge and health beliefs regarding phosphate-binding medication in predicting compliance. ANNA J. 1989;16(4):278-82.

23. Bame SI, Petersen N, Wray NP.Variation in hemodialysis patient compliance according to demographic characteristics. Soc Sci Med. 1993;37(8):1035-43.

24. Blackburn SL. Dietary compliance of chronic hemodialysis patients. J Am Diet Assoc. 1977;70(1):31-7.

25. Loghman-Adham M. Medication noncompliance in patients with chronic disease: issues in dialysis and renal transplantation. Am J Mang Care 2003, 9(2):155-71.

26. Claxton AJ, Cramer J, Pierce C. A systematic review of the associations between dose regimens and medication compliance. Clin Ther. 2001;23(8):1296-310.

27. Elixhauser A, Eisen SA, Romeis JC, Homan SM. The effects of monitoring and feedback on compliance. Med Care. 1990;28(10):882-93.

28. Stephenson BJ, Rowe BH, Haynes RB, Macharia WM, Leon $\mathrm{G}$. The rational clinical examination. Is this patient taking the treatment as prescribed? JAMA. 1993;269(21): 2779-81.

29. Pruijm MT, Teta D, Wuerzner G, Santschi V, Burnier M. Treatment of secondary hyperparathyroidism in dialysis: Report of a case-study of treatment failure. Nephrol Ther. 2008;4(1):28-33.

30. Rosner F. Patient noncompliance: causes and solutions. Mt Sinai J Med. 2006;73(2):553-9.

31. Gonsalves-Ebrahim L, Sterin G, Gulledge AD, Gipson WT, Rodgers DA. Noncompliance in younger adults on hemodialysis. Psychosomatics. 1987;28(1):34-41.

32. Sherman RA, Cody RP, Matera JJ, Rogers ME, Solanchick JC. Deficiencies in delivered hemodialysis therapy due to missed and shortened treatments. Am J Kidney Dis. 1994;24(6):921-3.

33. Avram MR, Pena C, Burrell D, Antignani A, Avram MM. Hemodialysis and the elderly patient: potential advantages as to quality of life, urea generation, serum creatinine, and less interdialytic weight gain. Am J Kidney Dis. 1990; 16(4):342-5.

34. Berman E, Merz JF, Rudnick M, Snyder RW, Rogers KK, Lee J, Johnson D, Mosenkis A, Israni A, Wolpe PR, Lipschutz JH. Religiosity in a hemodialysis population and its relationship to satisfaction with medical care, satisfaction with life, and adherence. Am J Kidney Dis. 2004;44(3): 488-97.

35. Murray AM. Cognitive impairment in the aging dialysis and chronic kidney disease populations: an occult burden. Adv Chronic Kidney Dis. 2008;15(2):123-32.

36. Hain DJ. Cognitive function and adherence of older adults undergoing hemodialysis. Nephrol Nurs J. 2008; 35(1):23-9.

37. Negredo E, Bonjoch A, Clotet B. Benefits and concerns of simplification strategies in HIV-infected patients. J Antimicrob Chemother. 2006;58(2):235-42.

38. Florman S, Alloway R, Kalayoglu M, Punch J, Bak T, Melancon J, Klintmalm G, Busque S, Charlton M, Lake J, Dhadda S, Wisemandle K, Wirth M, Fitzsimmons W, Holman J, First MR. Once-daily tacrolimus extended release formulation: experience at 2 years postconversion from a Prograf-based regimen in stable liver transplant recipients. Transplantation. 2007;83(12):1639-42.

39. Kaplan MR, Stashenko CL, Bledsoe AL, McGowan J. A preference study: calcium acetate tablets versus gelcaps in hemodialysis patients. Nephrol Nurs J. 2002;29(4):363-5.

40. Hutchison AJ, Laville M; on behalf of the SPD405-313 Lanthanum Study Group. Nephrol Dial Transplant. 2008;23(11):3677-84.

41. Wolf M, Thadhani R. Vitamin D in patients with renal failure: a summary of observational mortality studies and steps moving forward. J Steroid Biochem Mol Biol. 2007;103(3-5):487-90.
42. Andress D. Nonclassical aspects of differential vitamin D receptor activation: implications for survival in patients with chronic kidney disease. Drugs. 2007;67(14):19992012.

43. Kimmel PL, Weihs K, Peterson RA. Survival in hemodialysis patients: the role of depression. J Am Soc Nephrol. 1993;4(1):12-27.

44. Christensen AJ, Wiebe JS, Smith TW, Turner CW. Predictors of survival among hemodialysis patients: effect of perceived family support. Health Psychol. 1994;13(6):5215.

45. Wai L, Richmond J, Burton H, Lindsay RM. Influence of psychosocial factors on survival of home-dialysis patients. Lancet. 1981;2(8256):1155-6.

46. The Seventh Report of the Joint National Committee on Prevention, Detection, Evaluation, and Treatment of High Blood Pressure (JNC 7). Hypertension. 2003;42: 1206

47. Newmann JM, Litchfield WE. Newmann JM. Adequacy of dialysis: the patient's role and patient concerns. Semin Nephrol. 2005;25(2):112-9.

48. Haynes RB, Ackloo E, Sahota N, McDonald HP, Yao X. Interventions for enhancing medication adherence. Cochrane Database Syst Rev. 2008;(2)

49. So HS, Kim AY, Kim EA, Kim SM. Effects of a structured drug education program on knowledge and medication compliance for hemodialysis patients. Taehan Kanho Hakhoe Chi. 2006;36(7):1135-44.

50. Kammerer J, Garry G, Hartigan M, Carter B, Erlich L. Adherence in patients on dialysis: strategies for success. Nephrol Nurs J. 2007;34(5):479-86.

51. Cummings KM, Becker MH, Kirscht JP, Levin NW. Psychosocial factors affecting adherence to medical regiments in a group of hemodialysis patients. Med Care. 1982;20(6):567-80

52. Betts DK, Crotty GD. Response to illness and compliance of long-term hemodialysis patients. ANNA J. 1988;15(2):96-100.

53. Blanchard R, Berger W, Bailie GR, Eisele G. Knowledge of hemodialysis and CAPD patients about their prescribed medicines. Clin Nephrol. 1990;34(4):173-8.

54. Lin CC, Liang CC. The relationship between health locus of control and compliance of hemodialysis patients. Kaohsiung J Med Sci. 1997;13(4):243-54.

55. Horne R, Sumner S, Jubraj B, Weinman J, Frost S. Haemodialysis patients beliefs about treatment: Implications for adherence to medication and fluid-diet restrictions. Int Journal Pharmacy Prac 2001, 9(3): 169-75.

56. Tomasello S, Dhupar S; Sherman RA. Phosphate binders, K/DOQI guidelines, and compliance: The unfortunate reality. Dialysis \& Transplantation 2004, 33(5):236-42.

57. Rahman M, Griffin V. Patterns of antihypertensive medication use in hemodialysis patients. Am J Health Syst Pharm. 2004;61(14):1473-8.

58. Lindberg M, Lindberg P, Wikström B. Medication discrepancy: a concordance problem between dialysis patients and caregivers. Scand J Urol Nephrol. 2007;41(6): 546-52.

Received: November 18, 2008 / Accepted: March 31, 2009

Address for correspondence:

PD Dr. Holger Schmid

KfH Nierenzentrum Muenchen Laim

Elsenheimerstr. 63

80687 Munich

Germany

Tel.: $\quad++49895472670$

Fax: $\quad++49895705727$

E-mail: holger.schmid@1rz.uni-muenchen.de 